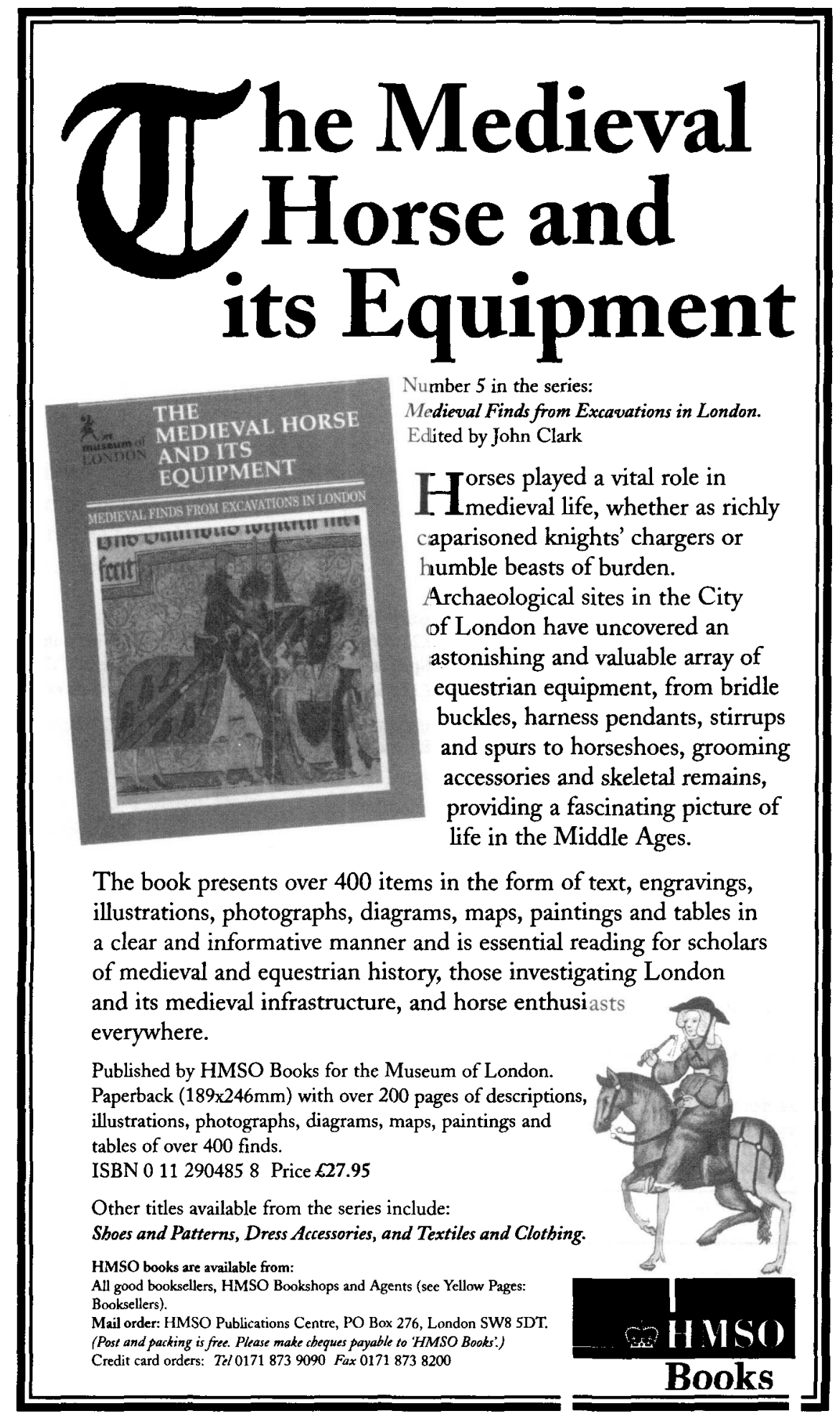




\section{PARLIAMENTARY HISTORY}

Parliamentary History provides a forum

for curreut research, and articles of a more general interest covering the history of parliamentary institutions in the British Isles (including the Scottish and Irish parliaments), and in former British colonies before independence, from the Middle Ages to the twentieth century.

\section{SUBSCRIPTION RATES}

Volume 14, 1995 ISSN- 0264-2824

Now 3 issues a year - February, June, October

Individuals:

UK \& EC $\quad £ 29.50$

Overseas $\quad \mathbf{E 4}$

N. America $\$ 56$
Institutions:

UK \& EC $\quad 59$

Overseas $\quad £ 68$

N. America $\$ 112$
Back Issues: Ł21.50/\$35 Special Issues: f12.95/\$20 ...worth the subscription of any scholar interested in the history of parliament.

\section{THES}

\section{HOW TO ORDER}

Return this form with your payment to:

Kathryn MacLean, Subscriptions

Edinburgh University Press Ltd

22 George Square

EDINBURGH

EH8 9LF, UK

\section{Please enter my subscription to Parliamentary History Volume I4, 1995}

I am interested in subscribing to Parliamentary History, please send me a free sample copy.

I enclose the correct remittance (please make cheques payable to Edinbungh University Press Ltd.)

Please debit my Visa/MasterCard - Account number

Expiry date

Name

Address 


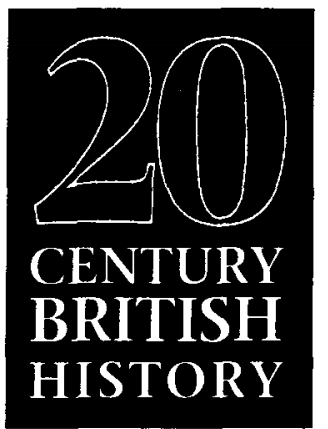

Editors: John Rowett, Brasenose College, Oxford Fred Leventhal, Boston University Kenneth O. Morgan, The University of Wales Review Editor: Ewen Green, University of Reading

Founded in 1990 on the premise that contemporary British history was relatively ill-served by existing periodical literature, Twentieth Century British History has led the initiative to meet that need with its wide range of lively and provocative articles. Interdisciplinary in scope, the journal links the many different and specialized branches of historical scholarship with work in political science and related disciplines. The journal seeks to transcend traditional disciplinary boundaries, in order to foster the study of patterns of change across the twentieth century.

The editors are committed to publishing work within an international comparative context. Features of the journal include original articles by younger writers as well as by established scholars, major review articles, debates, archive surveys, and reviews of historical work in other media.

A special issue of Twentieth Century British History on the Labour Party will be published in 1995 (Volume 6, No 2).

Recent $\&$ Forthcoming articles include:

- Michael Freeden The Stranger at the Feast: Ideology and Public Policy in TwentiethCentury Britain

- Lord Gilmour The Thatcher Memoirs

- Brian Harrison Thatcherism and the Intellectuals

- David Jarvis Mrs Maggs and Betty: The Conservative Appeal to Women Voters in the $1920 \mathrm{~s}$

- Joseph McAleer Scenes from Love and Marriage: Mills and Boon and the Popular Publishing Industry in Britain, 1908-1950

- Richard Morgan The Introduction of Civil Legal Aid in England and Wales

- John Peters The British Government and the City/Industry Divide

- Jean Seaton The Second World War in Television

- Tony Shaw Eden, the BBC and the Suez Crisis

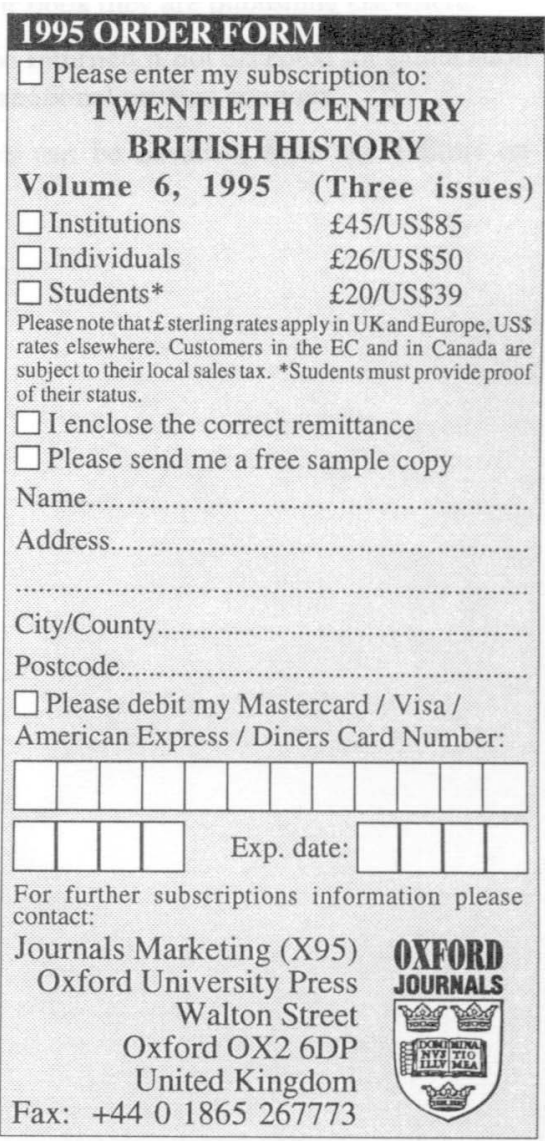


I All contributions, correspondence, and books for review should be sent to: The Editors, The Historical Fournal, Faculty of History, West Road, Cambridge CB3 9 EF.

2 The Historical Journal publishes articles on all aspects of history since the fifteenth century.

3 Articles must not exceed I0,000 words and communications 5,000 words in length.

4 Contributions should be typed double-spaced on $\mathrm{A}_{4}$ paper, with footnotes typed separately at the end of the contribution, and must observe the typographical and stylistic conventions of the Joumal. A style-sheet is available from the Editors on request.

5 Authors should submit the top copy of their typescript and keep another copy to assist in their correction of proofs. When an article has been accepted for publication, the author is strongly encouraged to send a copy of the final version on computer disk (Apple Macintosh or IBM compatible PC) together with the hard copy typescript, giving details of the wordprocessing software used (Microsoft Word, Word or Word Perfect). However, the publisher reserves the right to typeset material by conventional means if an author's disk proves unsatisfactory.

6 Submission of an article is taken to imply that it has not previously been published, and is not being considered for publication elsewhere. Authors are also asked to provide brief details of any related article or book they are publishing elsewhere.

7 Authors who wish their contributions to be returned if not accepted for publication are asked to enclose return postage or international postage coupons.

A more extensive Notes for Contributors can be obtained from the Editors on request. 


\section{THE \\ HISTORICAL \\ JOURNAL}

VOLUME 39 , I MARGH I996

\section{CONTENTS}

\section{ARTICLES}

Susan Brigden 'The shadow that you know': Sir Thomas Wyatt and Sir Francis Bryan at Court and in embassy

Tom Webster Writing to redundancy: approaches to spiritual journals and early modern spirituality

Amanda L. Capern The Caroline church: James Ussher and the Irish dimension

Tony Claydon William III's Declaration of Reasons and the Glorious Revolution

Julian Hoppit Patterns of parliamentary legislation $1660-1800$

Michael P. Fitzsimmons The National Assembly and the abolition of guilds in France

Jane Lewis The boundary between voluntary and statutory social service in the late nineteenth and early twentieth centuries

Mark Bevir Fabianism, permeation and Independent Labour

Peter 7. Henshaw Britain, South Africa and the sterling area: gold production, capital investment and agricultural markets $193^{1-1961}$

Catherine Merridale The 1937 census and the limits of Stalinist rule

COMMUNICATION

REVIEW ARTIGLES

OTHER REVIEWS

See page i for full list of contents

\section{CAMBRIDGE UNIVERSITY PRESS}



